\title{
Phyllochron and Productive Performance of Strawberry Cultivars: Impact of Different Regions of Origin in a Conventional Cultivation System
}

\author{
Leonardo Antonio Thiesen ${ }^{1}$, Maria Inês Diel ${ }^{2}$, Marcos Vinícius Marques Pinheiro ${ }^{1}$, Carine Cocco $^{3}$, \\ Daniele Cristina Fontana ${ }^{1}$, Evandro Holz ${ }^{1}$, Braulio Otomar Caron $^{1} \&$ Denise Schmidt ${ }^{1}$ \\ 1 Department of Agronomic and Environmental Sciences, Federal University of Santa Maria, Frederico \\ Westphalen Campus, Rio Grande do Sul, Brazil \\ ${ }^{2}$ Crop Science Departament, Federal University of Santa Maria, Rio Grande do Sul, Brazil \\ ${ }^{3}$ University of Caxias do Sul, Rio Grande do Sul, Brazil \\ Correspondence: Denise Schmidt, Department of Agronomic and Environmental Sciences, Federal University of \\ Santa Maria, Frederico Westphalen Campus, Rio Grande do Sul, Brazil. E-mail: denise@ufsm.br \\ Marcos Vinícius Marques Pinheiro, Department of Agronomic and Environmental Sciences, Federal University \\ of Santa Maria, Frederico Westphalen Campus, Rio Grande do Sul, Brazil. E-mail: macvini@gmail.com
}

Received: January 7, $2018 \quad$ Accepted: February 24, $2018 \quad$ Online Published: April 15, 2018

doi:10.5539/jas.v10n5p167 URL: https://doi.org/10.5539/jas.v10n5p167

\begin{abstract}
The seedlings selection and the strawberry cultivars choice are fundamental to the productive success of a cultivation. Thus, the objective of this work was to evaluate the production of two strawberry cultivars with seedlings from different origins, in a conventional cultivation system under the low tunnel. The experiment was conducted in a randomized complete block design, in a $2 \times 3$ factorial scheme, two cultivars (Albion and San Andreas) and three different nurseries (Low altitude region/BR, High altitude region/BR and seedlings imported from the of Patagonia Region/AR) totaling six treatments, with four replicates and eight plants per plot. Phyllochron, number and production of commercials and non commercial fruits were determined. To the qualitative analysis, the acidity, total soluble solids and the relation total soluble solids/titratable acidity were determined. It was possible to observe that the Albion cultivar from all sources and the San Andreas of high altitude/BR presented the highest phyllochron values. The production of commercial fruits was higher for the Albion cultivar from high altitude/BR and Patagonia/AR, and to San Andreas cultivar of low altitude/BR. It was concluded that the phyllochron varies according to the cultivar and place of origin of the seedlings, being San Andreas cultivar of the low altitude/BR the one that requires less amounts of degree-days to emit a leaf. The Albion (high altitude/BR) cultivar has higher phyllochron, high productive potential and less production of non-commercial fruits, and can be used as a substitute for imported seedlings (Patagonia/AR), which will reflect in the costs reduction to the implantation of strawberry crops.
\end{abstract}

Keywords: Fragaria x ananassa, degree-days, Albion, San Andreas, seedlings

\section{Introduction}

The strawberry cultivation (Fragaria $x$ ananassa) is carried out in several regions of the world. In 2011, the world production of strawberries reached, approximately, 4.5 million tons, with the United States, Spain, Japan, Italy, South Korea and Poland being the main producers of the fruit (Reisser Júnior et al., 2010). In Brazil, the planted area totals around 4,000 hectares, with an annual production of 105,000 tons of the fruit per year, and an average productivity of 30 tons per hectare, and in more technified areas it can reach 60 tons per hectare (Reisser Júnior et al., 2015). The same authors report that Rio Grande do Sul is the second largest Brazilian producer, with an average productivity of 32 tons per hectare. Among the producers, there are small rural farmers who generally use family labor for their cultivation, making it an activity of great economic and social importance. In addition, strawberry cultivation stands out for its high profitability, constituting an important source of income for farmers (Dias et al., 2007). 
The cultivar choice is fundamental for the productivity success, since the adaptation of a cultivar depends on the genotype-environment interaction, and should be recommended according to the growing region, because the productivity and quality of the fruits are determined by the temperatures, photoperiod, conditions of the soil and incidence of pests and diseases (Oliveira \& Bonow, 2012; Duarte Filho et al., 2007). The temperatre is the main factor, acting as a regulator of the physiological process affecting plant growth and development. The ideal temperatures for strawberry cultivation are 20 to $26^{\circ} \mathrm{C}$ in the daytime period and $15{ }^{\circ} \mathrm{C}$ in the nocturnal period (Verdial et al., 2009). Thus, to evaluate the cultivars performance and the speed of leaf emission, the phyllochron is used, which is defined as the time interval between the appearance of successive leaves in the main crown, which is directly related to the increase of the leaf area (Mendonça et al., 2012; Rosa et al., 2009). In order to quantify the temperature of the air in the plant time, it is used the thermal sum, which refers to the difference between the accumulation of the average temperature and the base temperature, expressed in degrees-days (Rosa et al., 2009).

For the commercial strawberries cultivation, it is recommended that plants be renewed annually, due to the high incidence of diseases and pests, in which they cause reductions in fruit production. With this, the acquisition of new seedlings can represent up to $24 \%$ of the annual cost of the crop production (Wrege et al., 2007). The propagation of the species is made by stolons, which originate from the parent plant under long photoperiod and high temperature conditions, with vigor and sanity being the fundamental prerequisites for a new crop implantation (Cocco et al., 2010). In Brazil, most of the seedlings produced do not reach a minimum standard of certification, because they present low crown size and high infestation of diseases, and constant phytosanitary treatments are necessary because the nursery soil is not sterilized before planting (Antunes \& Cocco, 2012). Thus, about $30 \%$ of the seedlings that are used for the crops formation in the country come from abroad, mainly from Argentina and Chile (Oliveira et al., 2005), increasing the costs of strawberry crops. The seedlings from Patagonia present better quality, mainly due to the high amount of cold hours that the seedlings receive at the time of their formation, which favors fruit production (Radin et al., 2011). However, these seedlings usually arrive later to the producer, causing delay of the beginning of the reproductive phase, whereas the national seedlings can be transplanted sooner, increasing the period of fruit production.

The combination of obtaining high quality seedlings, along with the correct cultivar choice are important tools to increase productivity in the strawberry crop. In addition, it is interesting to evaluate the influence of the place of production of the seedlings on the productive performance of the crop. Thus being, the objective of this work was to evaluate the phyllochron and production of two strawberry cultivars from different seedlings in a conventional low tunnel system.

\section{Method}

The work was conducted in the experimental field of the Universidade Federal de Santa Maria, Campus Frederico Westphalen located at $27^{\circ} 23.73^{\prime} \mathrm{S} ; 53^{\circ} 25,75^{\prime} \mathrm{W}$ and at an altitude of 493 meters, under low tunnels, from May to December in 2015. The soil of the experimental area is classified as typical dystrophic Red Latosol with a clayey texture, deep and well drained (Embrapa, 2013). By Köppen's classification, the region climate is Cfa-humid temperate type with hot summer, with maximum air temperatures in hotter months higher than $22{ }^{\circ} \mathrm{C}$ (Alvares et al., 2013).

The experimental design was a randomized complete block design, in a $2 \times 3$ factorial scheme, two cultivars (Albion and San Andreas, both of neutral days) and three different regions of origin of the seedlings [from the low altitude region (city of Agudo in the Central area of Rio Grande do Sul, Central/RS, at an altitude of 83 meters), high altitude region in Brazil (city of Farroupilha in the Serra Gaúcha, an area of Rio Grande do Sul, Serra Gaúcha/RS, at an altitude of 783 meters) and imported seedlings from Patagonia, Argentina (city of El Maitén, at an altitude of 720 meters)], totalizing six treatments, with four blocks, each experimental unit consisting of eight plants.

Soil preparation was carried out in a conventional way with plowing, disking and the confection of seedbeds. The fertilization was carried out according to the previous analysis of the soil, being calculated according to the crop requirements (Santos \& Medeiros, 2003). Before planting, chemical fertilizer was applied at a dose of 55 $\mathrm{g} / \mathrm{m}^{2}$, of the formula 10-20-10 and tanned bovine manure at a dose of $5.5 \mathrm{~kg} / \mathrm{m}^{2}$, on April $15^{\text {th }}, 2015$.

Seedlings planting occurred on the following dates: May $6^{\text {th }}$ for Albion and San Andreas (high altitude/BR); May $25^{\text {th }}$ for Albion (low altitude/BR) and June $15^{\text {th }}$ for San Andreas (low altitude/BR); June $8^{\text {th }}$ for Albion (Patagonia/AR) and June 22 $2^{\text {th }}, 2015$ for San Andreas (Patagonia/AR). The different planting dates were due to the delivery period of the seedlings by the suppliers. A spacing of $0.30 \times 0.30 \mathrm{~m}$ was used in seedbeds containing $1.2 \mathrm{~m}$ wide, $16 \mathrm{~m}$ long and four rows of plants. The experiment was conducted inside low tunnels constructed 
with transparent low density polyethylene, with a thickness of $100 \mu \mathrm{m}$, arranged in a north-south direction (Figure 1). Irrigation and fertigation were performed through drip tape, and the cultural treatments were performed according to the crop requirements. The monitoring of air temperature inside the tunnels was done by recording the minimum and maximum air temperature data.

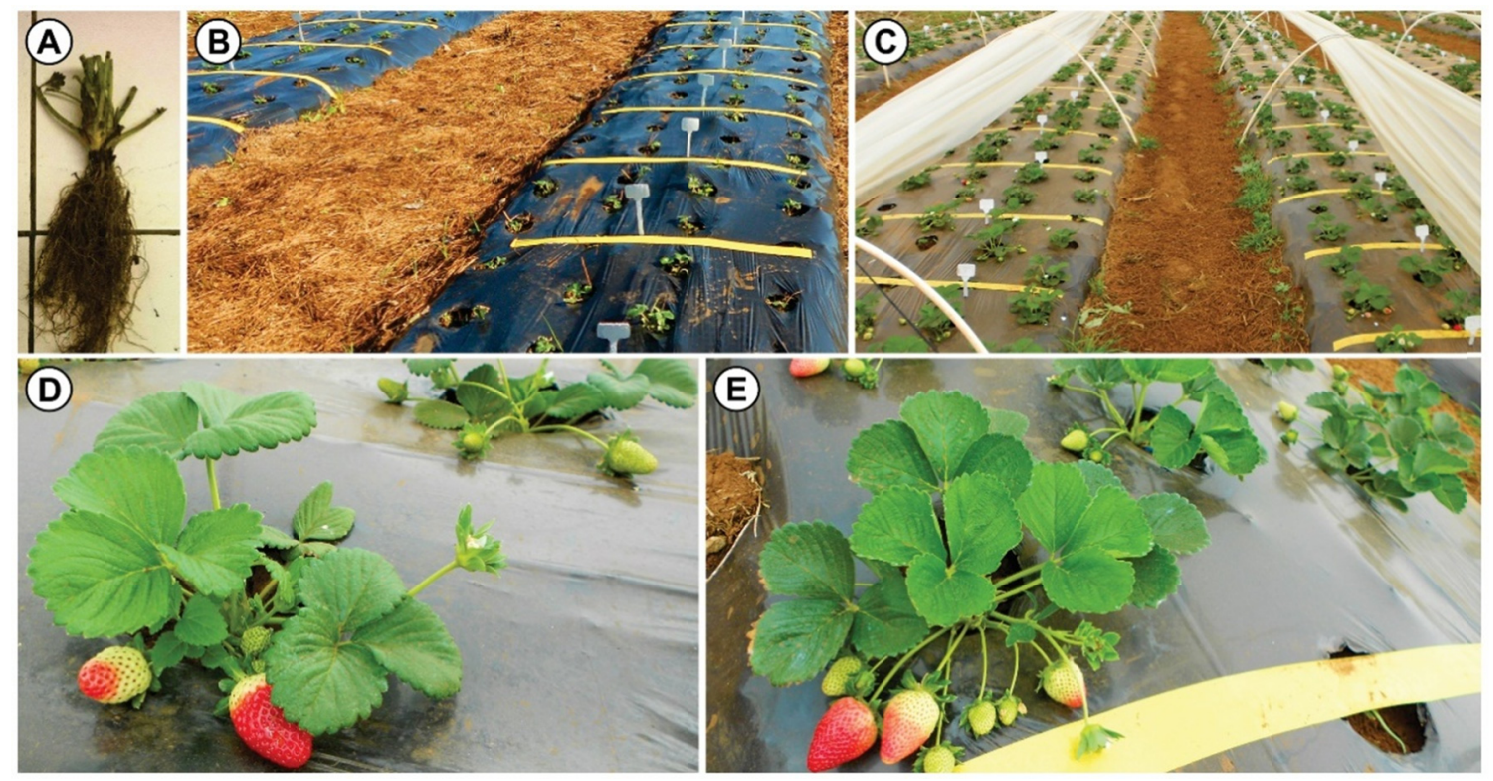

Figure 1. Strawberry cultivars (Albion e San Andreas) from different origins and cultivated inside low tunnel. Size of seedlings transplanted at the beginning of planting (A); strawberry cultivation in mulching inside low tunnel (B-C); grow and production of Albion (D-E)

During the course of the crop cycle, phyllochron, production parameters [number of commercial fruits (NCF), commercial fruit production (PCF), number of non-commercial fruits (NNCF) and non-commercial fruit production (PNCF)] and quality parameters [total titratable acidity (TTA), total soluble solids (TSS), relation total soluble solids and titratable acidity (TSS/TA)] were evaluated.

To determine the phyllochron, the number of crown leaves was counted every three days, from the transplant to the full bloom, during the period the plant emits the second floral raceme, following the methodology of Mendonça et al. (2012). For counting, a leaf was considered, when it was visible and the edges of the leaflets no longer touched.

The average air temperature was carried out using a data logger where the minimum and maximum air temperatures data inside the low tunnels was captured. The following formula was used to calculate the mean air temperature:

$$
T_{\text {ave }}=T_{\max }+T_{\min } / 2
$$

Where, $T_{\text {ave }}$ is the average air temperature; $T_{\max }$ is the maximum temperature; and $T_{\min }$ is the minimum temperature.

For the daily thermal sum $\left(\mathrm{ST}_{\mathrm{d}}\right)$, the following equation was suggested by Arnold (1960):

$$
S T_{d}=\left(T_{\text {ave }}-T_{b}\right) \cdot 1 \text { dia }\left\{{ }^{\circ} \mathrm{C} \text { day }\right\}
$$

Where, $\mathrm{ST}_{\mathrm{d}}$ is the daily thermal sum; $\mathrm{T}_{\mathrm{ave}}$ is the average temperature; $\mathrm{T}_{\mathrm{b}}$ is the base temperature.

The base temperature is one in which the plant did not develop or its development is so slow that it can be neglected (Rosa et al., 2013). For the strawberry, the base temperature of $7{ }^{\circ} \mathrm{C}$ was used (Mendonça et al., 2012).

The thermal sum was calculated from the transplant of the seedlings of each cultivar, and the accumulated thermal sum $\left(\mathrm{ST}_{\mathrm{a}}\right)$ was obtained, in which the sum of the daily thermal sum is calculated:

$$
S T_{a}=\sum S t d\left\{{ }^{\circ} \mathrm{C} \text { day }\right\}
$$


To estimate the phyllochron, a linear regression was performed between the number of emitted leaves and the accumulated thermal sum. In this way, the phyllochron $\left({ }^{\circ} \mathrm{C}\right.$ leaf day $\left.{ }^{-1}\right)$ was estimated to be the inverse of the angular coefficient of the linear regression (Mendonça et al., 2012).

The qualitative analyzes (total titratable acidity, total soluble solids, relation total soluble solids and titratable acidity) of the fruits were carried out in three moments during the crop cycle (15 days of August, September $25^{\text {th }}$ and October $15^{\text {th }}$ ), in order to eliminate specific characteristics of the harvesting season. The determination of TA was performed by titrimetry with a standard solution of $\mathrm{NaOH} 0.1 \mathrm{~mol} \mathrm{~L}^{-1}$ and the TSS determination was performed using a manual refractometer, with an accuracy of $\pm 2 \%$, with results expressed in ${ }^{\circ}$ Brix. The TSS/TA was performed by the quotient between the values of TSS and TA.

For the variables number of commercial fruits, commercial fruits production, number of non-commercial fruits and non-commercial fruits production, the harvests were carried out twice a week, in the phase of complete maturation, carrying out the separation of commercial fruits from non-commercial ones. For non-commercial fruits were considered those that were deformed, damaged or weighing less than 6 grams.

The results were submitted to analysis of variance, to evaluate the effects of the different strawberry cultivars and the different origins of the seedlings, and when they were significant, the averages of all the variables were compared by the Tukey's test, at 5\% of error probability, through Genes, a statistical program (Cruz, 2013).

\section{Results}

\subsection{Experimental Environmental Conditions}

In the data concerning the microclimate of the place during the conduction of the experiment, it was possible to observe the maximum and minimum air temperature recorded inside the tunnels during the conduction of the experiment, being 46.6 and $-0.7^{\circ} \mathrm{C}$, respectively, showing high thermal amplitude during the period (Figure 2).

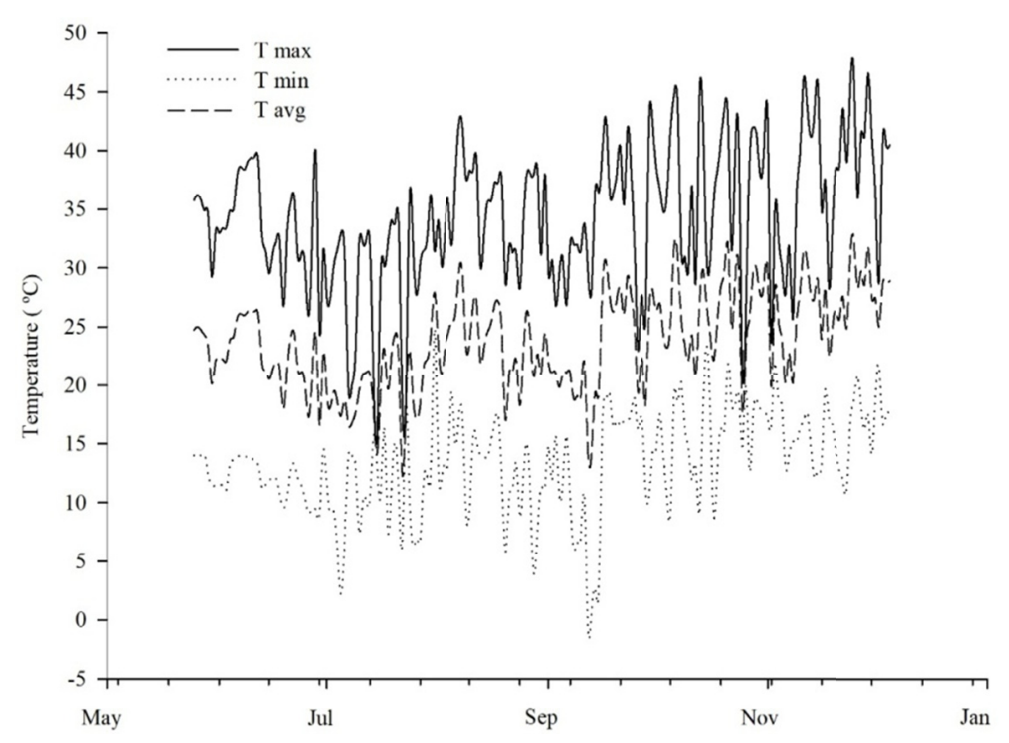

Figure 2. Maximum, minimum and average air temperatures recorded inside the tunnels with strawberry cultivation

\subsection{Phyllochron}

Analysis of variance demonstrated significant difference for the cultivar $\times$ origin interaction of the seedlings for the phyllochron, number and production of commercial fruit (NCF and PCF, respectively), number and production of non-commercial fruits (NNCF and PNCF, respectively) variables.

For the phyllochron variable, shown in Table 1, it was verified that in relation to the region of origin, there was difference only for the region of low altitude/BR, in which the Albion cultivar was significantly superior to San Andreas (256.7 and 92.2, respectively). When comparing within the same cultivar, there was no difference for Albion, independent of the region of origin of the seedlings $(\mathrm{p}<0.05)$. However, for San Andreas, it was 
possible to observe that the seedlings from the region of high altitude/BR (289.6) they presented higher phyllochron when compared to the other regions of origin $(\mathrm{p}<0.05)$.

Table 1. Phyllochron of strawberries cultivars from different regions of origin

\begin{tabular}{llc}
\hline \multirow{2}{*}{ Regions of origin } & \multicolumn{2}{c}{ Phyllochron $\left({ }^{\circ} \mathrm{C}\right.$ day leaf $\left.{ }^{-1}\right)$} \\
\cline { 2 - 3 } & Albion & San Andreas \\
\hline High altitude/BR & $276.4 \mathrm{aA}$ & $289.6 \mathrm{aA}$ \\
Low altitude/BR & $256.7 \mathrm{aA}$ & $92.2 \mathrm{bB}$ \\
Patagonia/AR & $182.1 \mathrm{aA}$ & $146.3 \mathrm{bA}$ \\
\hline CV $(\%)$ & 25.92 & \\
\hline
\end{tabular}

Note. ${ }^{*}$ Averages followed by the same lowercase letter in the column and upper case in the row do not differ by Tukey's test at $5 \%$ probability.

Albion cultivar from all the regions of origin and San Andreas from high altitude/BR presented higher phyllochron values, making them less vigorous when compared to San Andreas in the low altitude/BR and Patagonia/AR regions (Figure 3).

It was possible to observe that the plants of the national Albion cultivar, coming from the regions of high and low altitude/BR (Figures 3A and 3B) required a thermal sum greater than $2,000{ }^{\circ} \mathrm{C}$ day $^{-1}$ for emission of approximately 12 leaves, while the seedlings from Patagonia/AR required around $1,500{ }^{\circ} \mathrm{C}$ day $^{-1}$ of STa (Figure 3C). The San Andreas cultivar of high altitude/BR, presented higher temperature accumulation $\left(2,500^{\circ} \mathrm{C}\right.$ day $\left.^{-1}\right)$ for emission of greater number of leaves (11 leaves), when compared with the other origins (Figure 3D). Plants from low altitude/BR were the ones with the lowest thermal sum, in relation to the number of leaves emitted, being approximately $2,500{ }^{\circ} \mathrm{C}$ day $^{-1}$ for emission of 10 leaves and $1,300{ }^{\circ} \mathrm{C}$ day ${ }^{-1}$ for emission of 13 leaves in Albion and San Andreas cultivars, respectively (Figures 3B and 3E, respectively). 

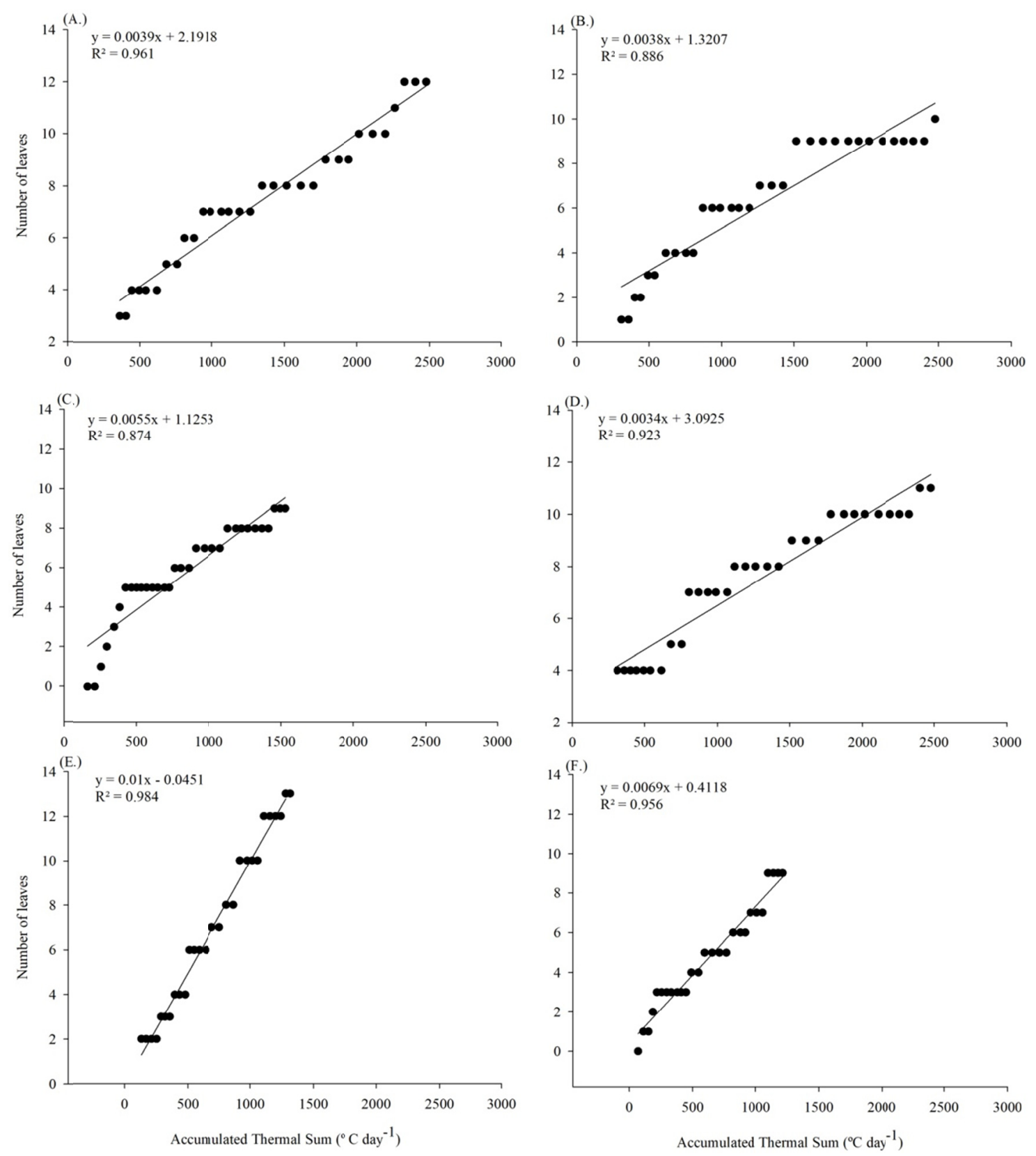

Figure 3. Linear regression between the number of leaves in the main crown and accumulated thermal sum (phyllochron) in strawberry cultivars from different regions of origin. (A) Albion (high altitude/BR), (B) Albion (low altitude/BR), (C) Albion (Patagonia/AR), (D) San Andreas (high altitude/BR), (E) San Andreas (low altitude/BR) and (F) San Andreas (Patagonia/AR)

\subsection{Number and Production of Commercial Fruits}

For the number of commercial fruits $(\mathrm{NCF})$ variable, in relation to the region of the seedlings origin, there was a significant difference only for the region of low altitude/BR, in which the San Andreas cultivar was superior when compared to Albion (20.9 and 7.6, respectively). When compared to the same cultivar, it was possible to observe that the Albion seedlings from high altitude/BR (17.7) and Patagonia/AR (16.4) showed higher numbers of fruits, not differing from each other $(\mathrm{p}<0.05)$. However, for the San Andreas cultivar, the region of low altitude/BR (20.9) was significantly higher when compared to the other regions evaluated (Table 2). 
Table 2. Number of commercial fruits (NCF) and production of commercial fruit (PCF) of strawberry cultivars from different regions of origin

\begin{tabular}{llllll}
\hline \multirow{2}{*}{ Regions of origin } & \multicolumn{2}{c}{ NCF } & & \multicolumn{2}{c}{ PCF $\left(\mathrm{g} \mathrm{plant}^{-1}\right)$} \\
\cline { 2 - 3 } \cline { 5 - 6 } & Albion & San Andreas & & Albion & San Andreas \\
\hline High altitude/BR & $17.7 \mathrm{aA}$ & $13.5 \mathrm{bA}$ & & $295.9 \mathrm{aA}$ & $173.6 \mathrm{aB}$ \\
Low altitude/BR & $7.6 \mathrm{bB}$ & $20.9 \mathrm{aA}$ & & $102.5 \mathrm{bB}$ & $273.5 \mathrm{aA}$ \\
Patagonia/AR & $16.4 \mathrm{aA}$ & $14.2 \mathrm{bA}$ & & $260.5 \mathrm{aA}$ & $260.9 \mathrm{aA}$ \\
\hline CV $(\%)$ & 21.88 & & 25.59 & \\
\hline
\end{tabular}

Note. * Averages followed by the same lowercase letter in the column and upper case in the row do not differ by Tukey's test at $5 \%$ probability.

For the PCF variable, when comparing within the same source region, there was a significant difference for the seedlings produced at high altitude/BR in which the Albion cultivar was superior to San Andreas (295.9 and 173.6, respectively). For the low altitude/BR region, the opposite was observed, in which the San Andreas cultivar was superior $(\mathrm{p}<0.05)$ to Albion $(273.5$ and 102.5 , respectively). When comparing within the same cultivar, there was a significant difference only for the Albion cultivar, in which the seedlings produced at high Altitude/BR and Patagonia/AR were superior when compared to the low altitude/BR region (295.9 and 260.5, respectively).

\subsection{Number and Production of Non-commercial Fruits}

For the NNCF variable, when evaluating the cultivar factor, it was possible to observe that there was no significant difference for both Albion and San Andreas (Table 3). However, when the factor of origin of the seedlings was evaluated, there was a significant difference only for those produced at low altitude/BR, in which San Andreas was significantly higher than Albion (8.4 and 2.5, respectively). For PNCF, when the cultivar factor was observed, there was a significant difference only for San Andreas, in which the low altitude/BR region was higher only when compared to high altitude/BR, in which it reached values of $29.7 \mathrm{~g} \mathrm{plant}^{-1}$. When the cultivar factor was evaluated, it was possible to observe a significant difference only for the seedlings produced in the region of low altitude/BR, in which the San Andreas cultivar (59.9) was significantly superior to Albion (16.9).

Table 3. Number of non-commercial fruits (NNCF) and production of non-commercial fruit (PNCF) of strawberry cultivars from different regions of origin

\begin{tabular}{|c|c|c|c|c|}
\hline \multirow{2}{*}{ Regions of origin } & \multicolumn{2}{|c|}{$\mathrm{NNCF}$} & \multicolumn{2}{|c|}{ PNCF $\left(\right.$ g plant $\left.^{-1}\right)$} \\
\hline & Albion & San Andreas & Albion & San Andreas \\
\hline High altitude/BR & $4.5 \mathrm{aA}$ & $4.6 \mathrm{aA}$ & $37.8 \mathrm{aA}$ & $29.7 \mathrm{aA}$ \\
\hline Low altitude/BR & $2.5 \mathrm{aB}$ & $8.4 \mathrm{aA}$ & $16.9 \mathrm{aB}$ & $59.9 \mathrm{bA}$ \\
\hline Patagonia/AR & $5.7 \mathrm{aA}$ & $5.1 \mathrm{aA}$ & $40.4 \mathrm{aA}$ & $41.4 \mathrm{abA}$ \\
\hline $\mathrm{CV}(\%)$ & 40.96 & & 40.26 & \\
\hline
\end{tabular}

Note. * Averages followed by the same lowercase letter in the column and upper case in the row do not differ by Tukey's test at $5 \%$ probability.

\subsection{Total Titratable Acidity, Total Soluble Solids and Relation Total Soluble Solids/Total Acidity}

From the analysis of variance, it was possible to observe that the qualitative variables of total titratable acidity (TTA), total soluble solids (TSS) and the relation total soluble solids/titratable acidity (TSS/TA) were not significant. It demonstrates that these variables were the same, that is, there was no difference in relation to the cultivars and the different places of origin of the seedlings. Therefore, the results show that the titratable acidity showed variations of 1.1 to $1.3 \%$ of citric acid in the different cultivars and regions of origin. The total soluble solids contents presented variations from 7.1 to $8.0^{\circ} \mathrm{Brix}$, while the relation of soluble solids has presented averages of approximately $6.5^{\circ}$ Brix (Figure 4 ). 

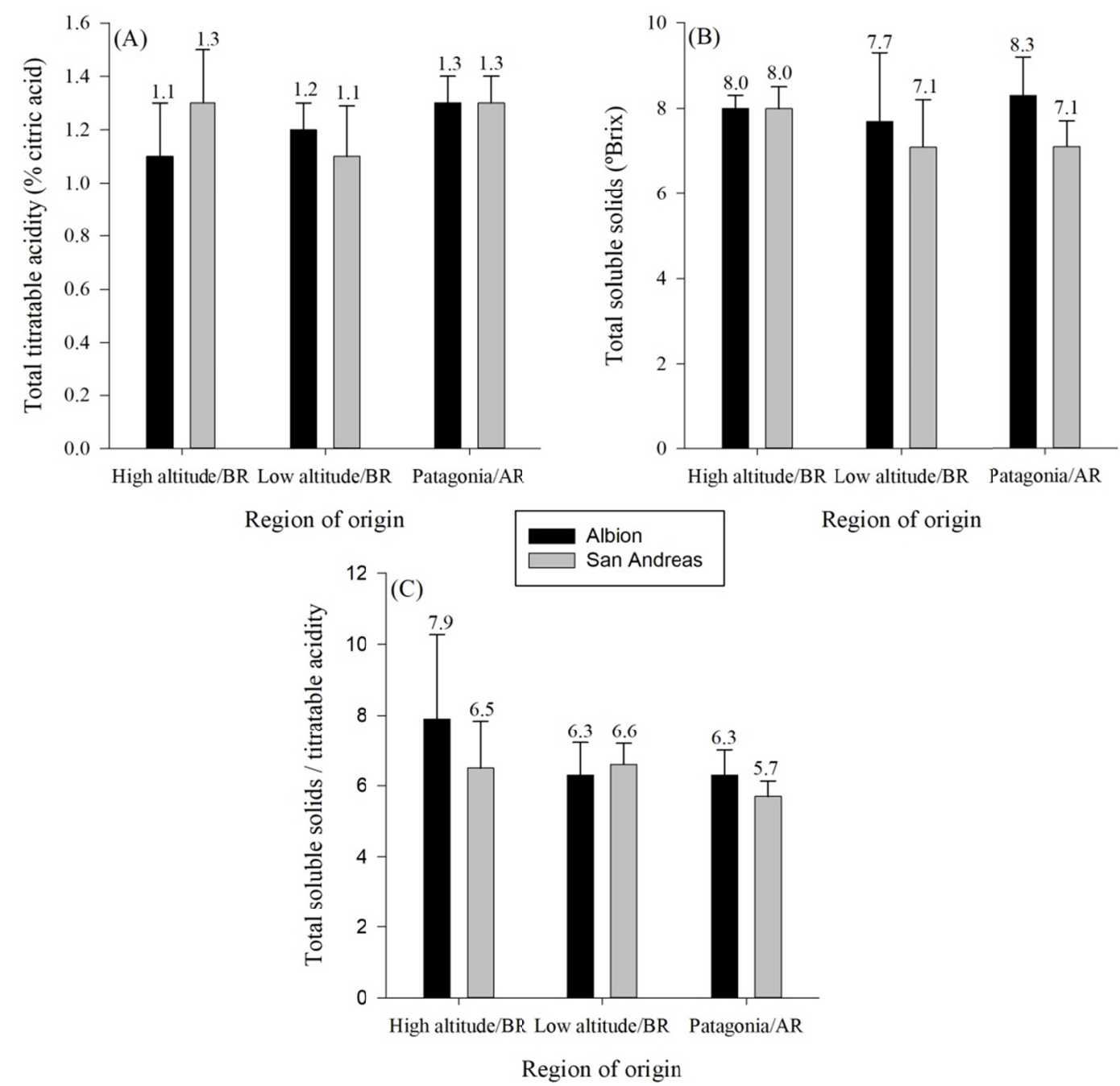

Figure 4. Total titritable acidity-TTA (A), total soluble solids-TSS (B) and the relation total soluble solids/titratable acidity-TSS/TA (C) results of strawberry cultivars of different origin of the seedlings were analyzed

\section{Discussion}

The lower leaf emission velocity in plants means that they require a higher thermal accumulation (Rosa, 2010), which confirms the higher precocity of the San Andreas seedlings from the low altitude region/BR and Patagonia/AR (Table 1). Tazzo et al. (2015) also observed a higher phyllochron value in the Albion cultivar when compared to San Andreas. Strawberry cultivars require different temperatures for their development (Mendonça et al., 2010; Rosa et al., 2011). With this, it was possible to observe that between the cultivars and the regions of origin of the seedlings, there are different thermal requirements, being fundamentally important to determine the choice of the cultivars, besides the management and the time of fruits harvest.

In the semi-hydroponic cultivation, Diel et al. (2017), found phyllochron values for the Albion cultivar, of 242.3 and $163.86^{\circ} \mathrm{C}$ day leaf ${ }^{1}$ with seedlings of national origin (low altitude/BR region) and imported (Patagonia/AR), respectively. These results were similar to those obtained in the present study, in soil cultivation, in which the phyllochron values were 256.7 and $182.1{ }^{\circ} \mathrm{C}$ day leaf ${ }^{1}$ for the same regions of origin.

Regarding the results of the regression, when the phyllochron value is high, it indicates that the cultivar has a slower leaf emission rate, requiring a greater accumulation of degree-days for the emission of each leaf (Walter et al., 2009; Rosa et al., 2013). This shows that plants of the Albion cultivar of national origin (low altitude/BR and high altitude/BR) require a higher accumulation of temperature for the emission of a leaf when compared to those imported from Patagonia/AR origin, proving that this characteristic is dependent on the cultivar genetic factor. The Albion and San Andreas cultivars, originated in Patagonia/AR, verified that the phyllochron variation 
is more affected by the environment than by the cultivar genetic constitution when compared to the main factors of production (cultivar, planting date and phyllochron phase). Therefore, the results in the present study may be correlated to local environmental conditions.

The results demonstrate that even the seedlings coming from the same region, the cultivars can express different responses and, thus, cause variations in the number and production of commercial fruits. Fruit production can be influenced by planting date (Rosa et al., 2013), demonstrating that yield varies according to environmental conditions.

The Serra Gaúcha region (high altitude) is a recommended place to produce strawberry seedlings in the state of Rio Grande do Sul, mainly due to the accumulation of cold hours that occurs between January and April, being fundamental for obtaining seedlings with high vigor and productive potential (Wrege et al., 2007). Watthier et al. (2011), evaluating the performance of strawberry cultivars in the region of Pelotas/RS, with seedlings from Argentina, obtained total fruit yield of $308.6 \mathrm{~g} \mathrm{plant}^{-1}, 305.8 \mathrm{~g}$ of commercial fruit production of the Albion cultivar. This production is higher than that obtained in the present work for the Albion cultivar. Already Carvalho et al. (2011) obtained average yields of 277.3 and $151 \mathrm{~g} \mathrm{plant}^{-1}$ to cultivate Albion and San Andreas, respectively, according to the results obtained in the present study.

The number of cold hours accumulated with temperatures between 2 and $7{ }^{\circ} \mathrm{C}$ recommended for the strawberry seedlings, should be from 380 to 700 hours (Ronque, 1998). Also according to the same author, some regions provide low temperature conditions, due to the latitude and/or high altitudes, providing a greater number of cold hours for the seedlings, which reflects in high productive potential. The results of the present work demonstrated that the Albion seedlings, from high altitude/BR, present productive potential similar to the seedlings from Patagonia/AR, without significant differences. However, if the production of the fruits with the phyllochron is compared, it can be observed that the Albion cultivar coming from high altitude/BR, even with a high phyllochron value $\left(276.4{ }^{\circ} \mathrm{C}\right.$ day leaf $\left.{ }^{1}\right)$, that is, less emission of leaves, was the one in which presented higher fruit production $\left(295.9 \mathrm{~g} \mathrm{plant}^{-1}\right)$. This demonstrates that fruit yield is not correlated directly with the phyllochron, but with the genetic characteristics and productive potential of each cultivar.

The San Andreas cultivar originates from the cross between Albion and a selection, from the University of California (Antunes, 2016). This cross was carried out to adapt the cultivar on the Central Coast and Southern California, being of neutral day. Therefore, because it is an improved cultivar, the tendency is that this one presents better results when compared to Albion. However, in the present work, it was observed that the San Andreas cultivar presented lower results of fruit production in the plants coming from high altitude/BR. This can be explained, due to the variation of the environment and the differences in the performance of the cultivars to the environments in which they are cultivated (Walter et al., 2009).

Neutral day cultivars have the capacity to produce in longer days and higher temperatures, and can be transplanted later, but the seedlings should receive more cold hours during the stay in nursery, to favor the maturation of these and the accumulation of reserves (Monegat \& Pagnan, 2015). However, it can be observed that the different environmental conditions of the seedlings region of origin were not the primary factor in which the plant physiology was altered, but rather the genetic and acclimatization characteristics of the cultivar to the environmental conditions in which they were submitted, because it was observed that the Albion and San Andreas cultivars, from the same region, presented opposite results. The region may provide more favorable conditions for one cultivar than for another because these conditions are favorable for the plants to be able to express their productive potentials.

With relation to the number and production of non commercial fruits, the greater amount of discarded production usually occurs when there are favorable conditions for the occurrence of pests and diseases (Watthier et al., 2011). These authors also report that the main cause of fruit discard is the classification by mass below the minimum determined for the fruit considered commercial (6 grams). Another factor that may lead to the occurrence of fruit discard is the genetic factor of the cultivars, which can often cause deformed fruits, failures in pollination, among others.

Thus, it was observed that the Albion cultivar of low altitude/BR, besides presenting inferior results of production of commercial fruits, also presented smaller results of production of non-commercial fruits. This shows that the seedlings origin, besides being important in relation to the productive potential, also becomes fundamental for the normal formation of the fruits. In order to avoid deformations in strawberry fruits, it is essential that the pollen be evenly distributed over the stigmas, and the shape of the fruits depends on the fertilized eggs and their distribution around the receptacle (Malagodi-Braga, 2002). That is, when flowering is affected, it may not produce fruits or even generate with deformations, classifying them as non-commercial fruits. 
They are also classified as non-commercial fruits those with rot, physical deformation, physiological anomalies, nutritional deficiencies and with attacks of fungi, insects or other predators (Duarte Filho et al., 2007). Thus, even if environmental factors influence strawberry production, the cultivar and the seedlings origin also influence productivity.

The results the total titratable acidity, total soluble solids and relation total soluble solids/ did not present differences to the cultivars and the regions of origin of the seedlings, but it can be verified that the averages obtained in the present study were similar to the results obtained by Carvalho (2013), which presented averages of 0.85 and $0.87 \%$ of citric acid and 7.92 and $7.68{ }^{\circ}$ Brix of TSS, for the Albion and San Andreas cultivars, respectively.

The flavor of the fruits are determined by the contents of total acidity, total soluble solids and the relation between them (Krüger et al., 2012). The total soluble solids content is an indication of the sugars amount concentrated in the fruits (Kluge et al., 2002), and the relation TSS/TA represents the fruit flavor, which is more representative than the TSS and TA variables separately, and for industry the processing takes place from a relation greater than 12-13 (Pinto, 2003). Carvalho (2013) obtained TSS/TA averages of 9.39 and 8.9 for Albion and San Andreas cultivars from Argentina, respectively, being superior. This demonstrates that the results obtained in the present study are below industry standards, which can be justified by fruit harvesting at an incomplete maturation stage with low ${ }^{\circ}$ Brix levels or even unfavorable environmental conditions to provide a sweet flavor to the fruits.

The study demonstrate that the phyllochron varies according to the cultivar and the place of origin of the seedlings, and the San Andreas cultivar from low altitude/BR region requires less amounts of degrees-day to emit a leaf. The Albion cultivar of national origin (high altitude/BR) presents a higher phyllochron, high productive potential and less production of non-commercial fruits, being able to be used instead of imported seedlings (Patagonia/AR), which will reflect in costs reduction in the implantation of strawberry crops.

\section{References}

Alvares, C. A., Stape, J. L., Sentelhas, P. C., Gonçalves, J. L. M., \& Sparovek, G. (2013). Köppen's climate classification map for Brazil. Meteorologische Zeitschrif, 22(6), 711-728. https://doi.org/10.1127/ 0941-2948/2013/0507

Antunes, L. E. C. (2016). Cultivares. Agência Embrapa de Informação Tecnológica, Embrapa. Retrieved from http://www.agencia.cnptia.embrapa.br/gestor/morango/arvore/CONT000fmxotm4d02wyiv8065610do1fgl2 q.html

Antunes, L. E. C., \& Cocco, C. (2012). Tecnologia para a produção de frutas e mudas do morangueiro. Agropecuária Catarinense, 25(2), 61-65. Retrieved from https://www.alice.cnptia.embrapa.br/bitstream/ doc/927731/1/LuisEduardoSenafrut12.pdf

Arnold, C. Y. (1960). Maximum-Minimum temperature as a basis for computing heat units. Journal of the American Society for Horticulture Science, 76, 682-692.

Carvalho, S. F. (2013). Produção, qualidade e conservação pós-colheita de frutas de diferentes cultivares de morangueiro nas condições edafoclimáticas de Pelotas-RS (Dissertação de Mestrado, Universidade Federal de Pelotas, Pelotas, Brasil).

Carvalho, S. F., Cocco, C., Picolotto, L., Ferreira, L. V., Gonçalves, M. A., \& Antunes, L. E. C. (2011). Produtividade de cultivares de morangueiro de dia neutro na região de Pelotas-RS. In Encontro de Pós-Graduação UFPel, 13, Pelotas. Anais... Pelotas. Retrieved from https://www.alice.cnptia.embrapa.br/ bitstream/doc/917729/1/CA00296.pdf

Cocco, C., Andriolo, J. L., Erpen, L., Cardoso, F. L., \& Casagrande, G. S. (2010). Development and fruit yield of strawberry plants as affected by crown diameter and plantlet growing period. Pesquisa Agropecuária Brasileira, 45(7), 730-736. https://doi.org/10.1590/S0100-204X2010000700014

Cruz, C. D. (2013). GENES-A software package for analysis in experimental statistics and quantitative genetics. Acta Scientiarum. Agronomy, 35(3), 271-276. https://doi.org/10.4025/actasciagron.v35i3.21251

Dias, M. S. C., Silva, J. J. C., Pacheco, D. D., Rios, S. A., \& Lanza, F. E. (2007). Produção de morangos em regiões não tradicionais. Informe Agropecuário, 28(236), 24-33.

Diel, M. I., Pinheiro, M. V. M., Cocco, C., Fontana, D. C., Caron, B. O., Paula, G. M., ... Schmidt, D. (2017). Phyllochron and phenology of strawberry cultivars from different origins cultivated in organic substracts. Scientia Horticulturae, 220(16), 226-232. https://doi.org/10.1016/j.scienta.2017.03.053 
Duarte Filho J., Antunes L. E. C., \& Pádua J. G. (2007). Cultivares. Informe Agropecuário, 28, 20-23.

Embrapa (Empresa Brasileira de Pesquisa Agropecuária). (2013). Sistema Brasileiro de Classificação de Solos (3rd ed.). Brasília, DF: Embrapa.

Kluge, R. A., Nachtigal, J. C., Fachinello, J. C., \& Bilhalva, A. B. (2002). Fisiologia e manejo pós-colheita de frutas de clima temperado (p. 214). São Paulo, BR: Edit. Rural.

Krüger, E., Josuttis, M., Nestby, R., Toldam-Andersen, T. B., Carlen, C., \& Mezzetti, B. (2012). Influence of growing conditions at different latitudes of Europe on strawberry growth performance, yield and quality. Journal of Berry Research, 2(3), 143-157. https://doi.org/ 10.3233/JBR-2012-036

Malagodi-Braga, K. S. (2002). Estudo de agentes polinizadores em cultura de morango (Fragaria x ananassa Duchesne-Rosaceae) (Tese Doutorado, Universidade de São Paulo, São Paulo, Brasil).

Mendonça, H. F. C., Calvete, E. O., Nienow, A. A., Costa, R. C., Zerbielli, L., \& Bonafé, M. (2012). Phyllochron estimation in intercropped strawberry and monocrop systems in a protected environment. Revista Brasileira de Fruticultura, 34(1), 15-23. https://doi.org/10.1590/S0100-29452012000100005

Mendonça, H. F. C., Müller, A. L., Tazzo, I. F., \& Calvete, E. O. (2010). Accumulated leaf number in strawberry cultivars grown in a greenhouse. Acta Horticulturae, 926, 295-300. https://doi.org/10.17660/ActaHortic. 2012.926.40

Monegat, V., \& Pagnan, H. A. (2015). Morangos-Qual variedade plantar? Campo \& Negócios. Retrieved from http://www.revistacampoenegocios.com.br/morangos-qual-variedade-plantar

Oliveira, A. C. B., \& Bonow, S. (2012). Pequenas frutas: Tecnologias de produção. Informe Agropecuário, 33(268), 21-26.

Oliveira, R. P., Nino, A. F. P., \& Scivittaro, W. B. (2005). Mudas certificadas de morangueiro: Maior produção e melhor qualidade da fruta. A Lavoura, 108(655), 35-38.

Oliveira, R. P., Scivittaro, W. B., \& Rocha, P. S. G. (2011). Produção de cultivares de morango, utilizando túnel baixo em Pelotas. Revista Ceres, 58(5), 625-631. https://doi.org/10.1590/S0034-737X2011000500013

Pinto, W. S., Dantas, A. C. V. L., Fonseca, A. A. O., Ledo, C. A. S., Jesus, S. C., Calafange, P. L. P., \& Andrade, E. M. (2003). Caracterização física, físico-química e química de frutos de genótipos de cajazeiras. Pesquisa Agropecuária Brasileira, 38(9), 1059-1066. https://doi.org/10.1590/S0100-204X2003000900006

Radin, B., Lisboa, B. B., Witter, S., Barni, V., Reisser Junior, C., Matzenauer, R., \& Fermino, M. H. (2011). Desempenho de quatro cultivares de morangueiro em duas regiões ecoclimáticas do Rio rande do Sul. Horticultura Brasileira, 29(3), 287-291. https://doi.org/10.1590/S0102-05362011000300005

Reisser Jr., C., Antunes, L. E. C., Aldrighi, M., \& Vignolo, G. (2015). Panorama do cultivo de morangos no Brasil. Campo \& Negócios, Informe Técnico, Universidade Federal de Pelotas. Retrieved from http://www.revistacampoenegocios.com.br/panorama-do-cultivo-de-morangos-no-brasil

Reisser Junior, C., Antunes, L. E. C., \& Radin, B. (2010). Produção de morango (p. 216). In V Simpósio do morango e IV Encontro sobre pequenas frutas e frutas nativas do Mercosul. Anais... Pelotas, Embrapa Clima Temperado.

Ronque, E. R. V. (1998). Cultura do morangueiro: revisão e prática (p. 206). Curitiba: Emater IPR.

Rosa, H. T. (2010). Emissão e crescimento de folhas e seus efeitos na produção de frutas de duas cultivares de morangueiro (Dissertação Mestrado, Universidade Federal de Santa Maria, Santa Maria, Brasil).

Rosa, H. T., Streck, N. A., Walter, L. C, Andriolo, J. L., \& Silva, M. R. (2013). Crescimento vegetativo e produtivo de duas cultivares de morango sob épocas de plantio em ambiente subtropical. Revista Ciência Agronômica, 44(3), 604-613. https://doi.org/10.1590/S1806-66902013000300024

Rosa, H. T., Walter, L. C., Streck, N. A., \& Alberto, C. M. (2009). Métodos de soma térmica e datas de semeadura na determinação de filocrono de cultivares de trigo. Pesquisa Agropecuária Brasileira, 44(11), 1374-1382. https://doi.org/10.1590/S0100-204X2009001100002

Rosa, H. T., Walter, L. C., Streck, N. A., Andriolo, J. L., Silva, M. R., \& Langner, J. A. (2011). Base temperature for leaf appearance and phyllochron of selected strawberry cultivars in a subtropical environment. Bragantia, 70(4), 939-945. https://doi.org/10.1590/S0006-87052011000400029

Santos, A. M., \& Medeiros A. R. M. (2003). Morango: Produção. Frutas do Brasil (p. 81). Embrapa Clima Temperado. 
Tazzo, I. F., Fagherazzi, A. F., Lerin, S., Kretzschmar, A. A., \& Rufato, L. (2015). Exigência térmica de duas seleções e quatro cultivares de morangueiro cultivado no planalto catarinense. Revista Brasileira de Fruticultura, 37(3), 550-558. https://doi.org/10.1590/0100-2945-097/14

Verdial, M. F., Tessarioli Neto, J., Minami, K., Scarpare Filho, J. A., Christoffoleti, P. J., Scarpare, F. V., \& Kluge, R. A. (2009). Fisiologia de mudas de morangueiro produzidas em sistema convencional e em vasos suspensos. Revista Brasileira de Fruticultura, 31(2), 524-531. https://doi.org/10.1590/S0100-29452009 000200029

Walter, L. C., Rosa, H. T., Silva, M. R., Langer, J. A., \& Streck, N. A. (2009). Filocrono de dois clones de morangueiro em diferentes datas de plantio em Santa Maria, RS. In XVI Congresso Brasileiro de Agrometeorologia. Belo Horizonte, Anais... [CD-ROW].

Watthier, M., Silva, D. R., Schwengber, J. E., Moraes, R. T., Zanata, T., \& Pereira, C. V. (2011). 11567-Produção de morangueiro a partir de mudas de origem Argentina em sistema de produção de base ecológica. Caderno de Agroecologia, 6(2).

Wrege, M. S., Reisser Júnior, C., Antunes, L. E. C., Oliveira, R. P., Herter, F. G., Steinmetz, S., ... Santos, A. M. (2007). Zoneamento agroclimático para produção de mudas de morangueiro no Rio Grande do Sul (p. 30). Pelotas: RS, Embrapa Clima Temperado. Retrieved from https:/www.infoteca.cnptia.embrapa.br/infoteca/ bitstream/doc/745906/1/documento187.pdf

\section{Copyrights}

Copyright for this article is retained by the author(s), with first publication rights granted to the journal.

This is an open-access article distributed under the terms and conditions of the Creative Commons Attribution license (http://creativecommons.org/licenses/by/4.0/). 